\title{
Um enfoque no caráter religioso de Sócrates
}

\author{
Maira de Cinque Pereira \\ Orientador: Roberto Bolzani \\ PET
}

Esse trabalho busca enfocar o caráter divino de Sócrates ou a visão missionária que Sócrates tem de si mesmo. São diversas as passagens em que fica clara a sua concepção de que seu trabalho como filófoso tem raízes em algo que transcende as razões humanas. Sócrates considera-se como estando a serviço do deus. Esse aspecto missionário merece ser estudado dado que não são poucas as referências a esse tema dentro da "Apologia de Sócrates" Fica evidente, através da leitura deste texto, que Sócrates não se julgava um ser humano comum, com propósitos mundanos comuns, mas como alguém enviado pelo deus com a missão de despertar os homens do seu sono.

Na História da Filosofia, Sócrates é conhecido como alguém que lançou questões essenciais para o desenvolvimento dessa matéria, dando um sentido próprio para a ocupação de filósofo em oposição aos sofistas que, além de cobrarem pelos seus ensinamentos, consideravam-se como donos de uma verdade aparente e relativa. $\mathrm{O}$ filósofo, para Sócrates, deveria ser alguém que em primeiro lugar reconhece que nada sabe e tem a consciência da sua ignorância. Pois reside nesse reconhecimento a única sabedoria humana possível.

Mas apesar de Sócrates ser considerado como alguém que teve papel fundamental para a sistematização das questões filosóficas, enfocarei minha pesquisa em um caráter que ele sem dúvida assumiu durante sua vida. Sócrates considera-se como estando a serviço do 
deus, foi-lhe designada a tarefa árdua de "despertar os homens do seu sono" e conduzi-los à prática da virtude. Árdua, pois muitos pensam que sabem uma porção de coisas e passam-se por sábios, enganando a todos e, principalmente, a si mesmos. Difícil é fazê-los chegar ao conhecimento de que nada sabem para que então busquem puramente a verdade. É pela execução dessa tarefa que Sócrates tornou-se odiado, pois no momento em que Sócrates, impulsionado pelo deus, passa a interrogá-los, é exposta a ignorância daqueles que se julgam sábios.

$\mathrm{Na}$ tentativa de orientar os homens, Sócrates acaba por ridicularizar aqueles que nada sabem e julgam saber. Essa exposição ultrapassou o limite da antipatia e gerou um ódio que, em última instância levou Sócrates à condenação e à morte. E apesar de ter-lhe sido proposta a decisão sobre sua última sentença, ele decide-se pela morte, dado que não podia separar-se da sua missão. Sua decisão é de extrema coerência dado que viveu e morreu pela filosofia. Foi-lhe oferecido que decidisse qual seria sua pena, mas Ele manteve-se irredutível quanto a impossibilidade de deixar a filosofia, visto que a filosofia não é um capricho, mas uma missão divina.

Atenienses, eu vos sou reconhecido e vos quero bem, mas obedecerei antes ao deus que a vós; enquanto tiver alento e puder fazê-lo, jamais deixarei de filosofar, de vos dirigir exortações, de ministrar ensinamentos em toda ocasião àquele de vós que eu deparar...29d

Nesse momento Sócrates afirma que não poderá deixar a filosofia, já que esta seria sua obrigação junto ao deus. E mesmo que a cidade desaprove sua ocupação e suas atitudes, Sócrates está certo que a vontade do deus deve sobrepor-se a todas as demais. Dessa maneira, ele persiste na obediência ao deus "ainda que tenha que morrer muitas vezes" $30 \mathrm{c}$.

0 caráter divino de Sócrates expresso na Apologia

Logo nos primeiros parágrafos da "Apologia de Sócrates" fica clara uma distinção entre a verdade e a oratória. Essa contraposição 
será importante em vários momentos do texto, e em especial porque Sócrates se coloca como filósofo e amante da verdade em oposição aos sofistas que professam falsos conhecimentos por remuneração. Enquanto Sócrates diz a verdade "inteira" e "simples", essas pessoas utilizam-se de linguagem complexa e recursos elaborados para ludibriar os ouvintes, pois essa eloqüência exerce tal influência sobre os espíritos que faz com que o erro prevaleça sobre a verdade. Trata-se de um discurso enganador que levou, no caso da acusação de Sócrates, à calúnia. Diz Sócrates que seus acusadores, dada a sua força de persuasão, quase o fizeram esquecer quem era.

A diferença entre Sócrates e os chamados professores está na ciência que possuem. Enquanto Sócrates diz possuir uma ciência humana, os sofistas parecem possuir uma ciência sobre-humana. A ciência de Sócrates, segundo ele mesmo, é a única que um homem pode possuir: saber que nada sabe. Ao contrário disso, há aqueles que passam a dissertar sobre coisas que nem de longe conhecem, apesar de acreditarem que as conhecem profundamente. Um exemplo de tal atitude dentro da Apologia é a denúncia de Meleto. Sócrates mostra que seu acusador não tem conhecimento sobre o que seria bom e ruim para a juventude e que, portanto, não poderia acusá-lo de corromper os mais jovens, dado que corromper significa desviar alguém daquilo que é bom ou correto. Dessa forma, ao alegar que "Sócrates é réu de corromper a mocidade" mostra-se ignorante sobre sua própria acusação.

Ao contrário dos demais, Sócrates parte do princípio de que nada sabe. Ele constatou, a partir do Oráculo de Delfos, que a sabedoria de que tratava a Pítia em sua revelação era o reconhecimento da própria ignorância. Por esse motivo Sócrates é reconhecido pelo Oráculo como o mais sábio: ele é o único a crer que nada sabe frente àqueles que julgam saber detalhes sobre o céu e a terra.

Essa revelação não foi de pronto aceita por Sócrates, pois ele nunca se considerou nem muito nem pouco sábio. Mas pela confiança em tão idôneo autor, ele passa a interrogar cada pessoa que consi- 
dera sábia ou é tida por todos como sábia a fim de desvendar a sentença proferida pelo Oráculo. Sócrates descobre que a sua sabedoria reside na consciência de que nada sabe, pois apesar de todas essas pessoas tidas por sábias não saberem nada (assim como Sócrates), pensam que sabem alguma coisa e dessa forma permanecem estagnadas, conformadas com a ignorância que têm e nem suspeitam.

É nesse momento que Sócrates transforma o oráculo em missão: ele está a serviço do deus, seu dever é expor a ignorância e convencer a trilhar o caminho rumo à virtude.

parece-me que o deus me impôs à cidade com essa incumbência de me assentar perto, em toda parte, para não cessar de vos despertar, persuadir e repreender um por um. $30 e$

Todo seu trabalho é despertar as pessoas de seu sono, para que passem a buscar a verdade. E essa busca é idêntica à busca da virtude, dado que o conhecimento real não está atrelado à conquistas mundanas, mas ao aprimoramento da alma. Portanto, o seu papel é convencer a todos a cuidarem com mais afinco da virtude em lugar de cuidarem das riquezas, da fama e das honrarias, pois da virtude provém todas as demais coisas e não o contrário.

outra coisa não faço senão andar por aí persuadindo-vos, moços e velhos, a não cuidar tão aferradamente do corpo e das riquezas como de melhorar o mais possível a alma (...)

E Sócrates está certo de que sua missão é benéfica e de que todos deveriam usufruir desse verdadeiro presente dado à cidade. No tribunal ele diz que jamais aconteceu bem maior do que sua obediência ao deus e quem realmente perderá com a sua morte é a própria cidade que o condena.

Neste momento, Atenienses, longe de atuar na minha defesa, como poderiam crer, atuo na vossa, evitando que, com a minha condenação, cometais uma falta para com a dádiva que recebestes do deus" $30 \mathrm{~d}$

Mas há um momento especial do texto em que ele abandona até mesmo a convicção de que é um homem como qualquer outro. 
Sócrates afirma que sua natureza é distinta da natureza humana, pois não demonstra nenhum interesse nos assuntos que mais atraem a atenção das pessoas e dispõe-se a cuidar de toda a cidade. Através desse raciocínio, ele procura persuadir a todos de que é um enviado do deus à cidade, seu interesse único é servir como pai ou irmão mais velho conduzindo a quem quer que o deseje a despertar de seu sono em direção da busca da verdade.

Outro igual não tereis facilmente, senhores, mas, se me crerdes, vós me poupareis. Bem pode ser que, aborrecidos como quem dormia e foi despertado, deis ouvidos à Ânito e, repelindo-me, me condeneis levianamente à morte; depois, passareis o resto da vida a dormir, salvo se o deus, cuidadoso de vós, vos enviar algum outro. Podeis reconhecer que sou bem um homem dado pelo deus à cidade por essa reflexão: não é conforme a natureza do homem que eu tenha negligenciado todos os meus interesses, sofrendo, há tantos anos, as consequiências desse abandono do que é meu, para me ocupar do que diz respeito a vós, dirigindo-me sem cessar a cada um em particular, como um pai ou um irmão mais velho, para persuadir a cuidar dar virtude.31a-b

\section{Bibliografia}

PLATÃO. Apologia de Sócrates. São Paulo: Abril Cultural, 1973. (Coleção Os Pensadores) 